\title{
The Growth of Abalone (Haliotis squamata) in Net Floating Cage at Hulaliu Waters, Central District of Moluccas
}

\author{
Jacqueline M.F. Sahetapy and Magdalena Latuihamallo \\ The Aquaculture study Program, Fisheries and Marine Science Faculty, Pattimura University Ambon Indonesia \\ Email:jmf_sahetapy@yahoo.com; Magda_latu@yahoo.co.id
}

\begin{abstract}
Jacqueline M.F. Sahetapy and Magdalena Latuihamallo. 2014. The Growth of Abalone (Haliotis squamata) in Net Floating Cage at Hulaliu Waters, Central District of Moluccas. Aquacultura Indonesiana, 15 (1) : 21-25. Growth of abalone Haliotis squamata were studied over 5 weeks in net floating cages at Hulaliu waters, the Central District of Mollucas. The objectives of the research were to analyze a daily growth rate and absolute growth of abalone Haliotis squamata in net floating cage. A total of 45 abalones were observed, with average initial weight ranged of 8.0-8.5 g. The abalones were treated with 3 types of natural foods, and 3 replications were held. The foods type treatment were using 2 species of macroalga namely Ulva sp., Gracillaria sp., and combination of Ulva sp. and Gracillaria sp.. The water quality was monitored twice a day included water temperature $\left(28.1-29.9^{\circ} \mathrm{C}\right), \mathrm{pH}(7-8.5)$, dissolved oxygen $(8.2-10.1 \mathrm{mg} / \mathrm{L})$ and water salinity $(29.6-34$ ppt). The highest daily growth rate of weight was gained in Ulva sp. treatment which had rate of $0.068 \mathrm{~g} / \mathrm{day}$ at the fifth week, and also the absolute growth of weight was obtained in Ulva sp. treatment which had rate of $4.0 \mathrm{~g}$ in 56 days.
\end{abstract}

Keywords : Growth; Haliotis squamata; Net floating cage

\section{Introduction}

Abalone Haliotis squamata is one of the prospective waters commodity and has a high economic value, caused by its superiority like high in nutritional contents which good for health (protein $71.99 \%$, fat $3.2 \%$, fibre $5.6 \%$, ash $11.11 \%$, water $0.6 \%$ ) (Latuihamallo, 2011), and also its esthetics value of its shells which could be used in handicraft. The higher demand of this species which also affected to its price causing overexploitation for this species. There was found that the level of the exploitation became critical, signed by the more difficult in finding the species in its nature habitat. It had to be worried that one day the population of abalone could become extinct. To solve this problem, abalone is needed to be cultured.

Abalone could be cultured in many conditions, the laboratory scale or direct in the sea, and one method that could be used to culture abalone was using Net Floating Cage Method. A better technology of cultivation was needed whether in laboratory scale or in its nature habitat including food management, media engineering, breedstock management for hatching and water quality management (Fallu, 1991).

This research was aimed to analyze daily growth rate and absolute growth of abalone cultured in net floating cage in Hulaliu waters. This research hopefully could provide the more efficient, effective, productive and eco-friendly technology. Thus, the research was held with an accurate concept of abalone culture considering the resources and the geographical aspect.

\section{Material and Methods}

\section{Tool and Material}

The tools used in the research i.e: net floating cage, boat, plastic container, plastic basket, nylon, thermometer, refractometer (ATAGO), DOmeter (Type H19023), pHmeter (Hanna Type H198107) Caliper, and digital scales. While the material was abalone $H$. squamata with average weight ranged of 8.0-8.5 g about 45 individuals.

\section{Abalone culture}

Abalone cultured in net floating cage sized $3 \times 3 \mathrm{~m}^{2}$ by putting each individu of abalone into plastic basket and each basket contained 5 individu abalone. The natural foods used in the research were 2 types of alga (Ulva sp. and Gracilaria sp.) and combination of both of them. Food percentage was about $25 \%$ of its weight where the weight was being measured every 5 days (Latuihamallo, 2011).

\section{Data Analysis}

\section{a. Daily Growth Rate of Abalone}

Daily growth rate of abalone was calculated using a formula based on Zonneveld et al. (1991): 


$$
\mathrm{G}=\left(\mathrm{W}_{\mathrm{T}}-\mathrm{W}_{0}\right) / \mathrm{T}
$$

where :

G : Daily Growth Rate (g/day)

$\mathrm{W}_{0}$ : Weight of abalone at initial day of research (g)

$\mathrm{W}_{\mathrm{t}}$ : Weight of abalone at the latest day of research $(\mathrm{g})$

b. Absolute Growth of Abalon

Absolute growth was using formula based on Effendi (1979) :

$$
\mathrm{B}_{\mathrm{m}}=\mathrm{B}_{\mathrm{t}}-\mathrm{B}_{\mathrm{o}}
$$

where :

$\mathrm{B}_{\mathrm{m}}$ : Absolute growth of abalone

$\mathrm{B}_{\mathrm{t}}$ : Weight of abalone at the latest day of research $(\mathrm{g})$

$\mathrm{B}_{\mathrm{o}} \quad$ : Initial weight $(\mathrm{g})$

Results

Daily Growth Rate and Absolute Growth of Abalone Haliotis squamata
At initial day of research, weight of abalones were found in certain equal range of size. Figure 1 showed that abalone with different type of food treatment were in the growth increasing over 5 weeks of culturing. Figure 1 showed that abalone with Ulva sp. as its food had the highest rate of growth, compared with other types of food,Gracillaria sp. and the combination of both alga. At the first week of culture was found that all types of food giving the same value to both daily growth rate and absolute growth (0.001 g/day), then at the second week Ulva sp. showed higher value than others which finally gained $0.068 \mathrm{~g} /$ day at the fifth week.

Result of absolute growth of abalone during the period of research showed that there were different rates among the three treatments, where the abalone fed with Ulva sp. showed faster growth rate during 5 weeks of culture and being the highest at the end of research, weight $4.0 \mathrm{~g}$, followed with Gracillaria sp. treatment, weight $2.6 \mathrm{~g}$ and $1.8 \mathrm{~g}$ in alga combination treatment (Figure 2).

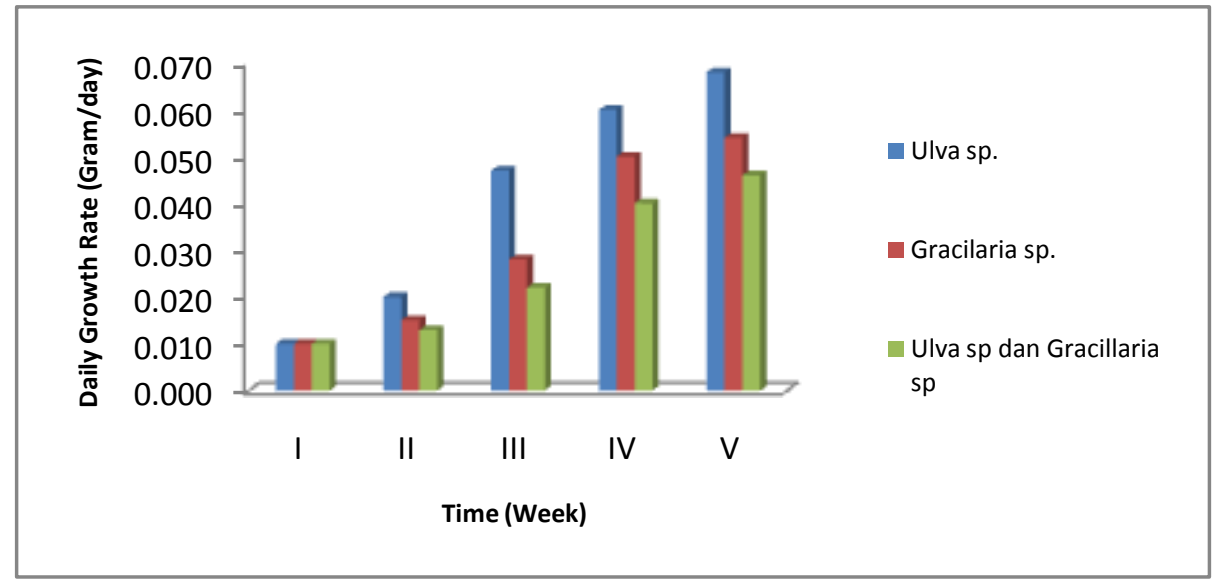

Figure 1. Daily Growth Rate of Abalone Haliotis squamata in Net Floating Cage At HulaliuWaters

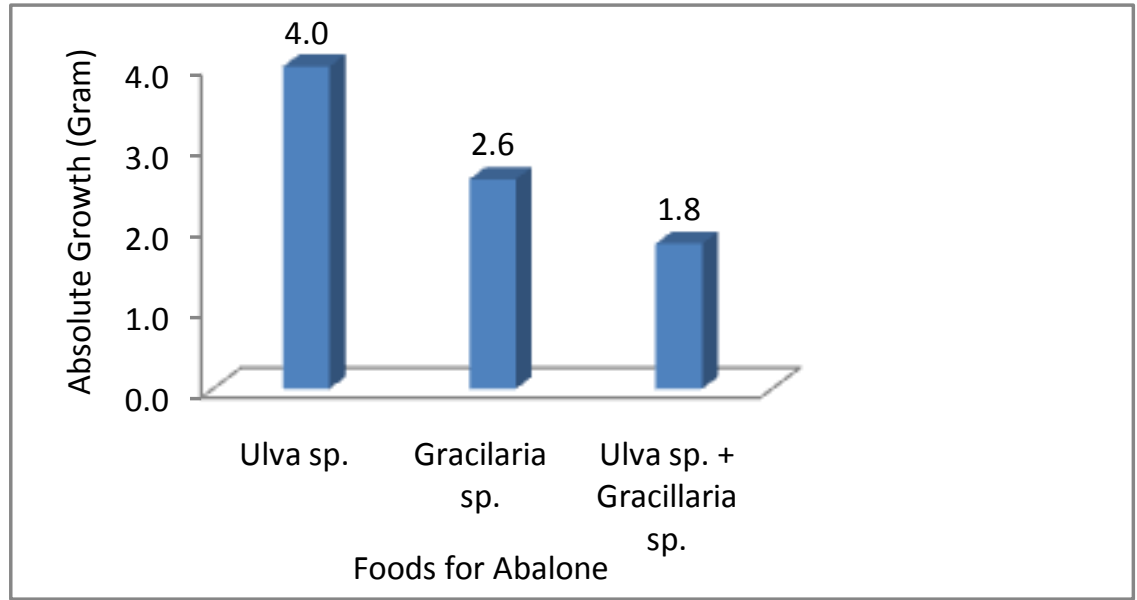

Figure 2. The Absolute Growth of Abalone Haliotis squamata in Net Floating Cages 
Water quality measured during the research showed that waters where the culture were held was in optimal rate for aquaculture, especially abalone culture. The temperature ranged at $28.1-29.9^{\circ} \mathrm{C}$, salinity ranged at 29.6 $34 \mathrm{ppt}, \mathrm{pH}$ ranged at 7-8.5 dan DO ranged at 8.2$10.1 \mathrm{mg} / \mathrm{L}$.

\section{Discussion}

Figure 1 showed the graphic of daily growth rate of abalone which could be interpretating the abalone's preference to certain type of food. It was assumed that abalone feed based on its need. While at the second week clearly showed that weight of abalone increased faster at Ulva sp. treatment. Thus, it could be assumed that abalone had preference to Ulva sp. as its natural food.

Rahmawati et al. (2008) stated that alga Ulva sp. and Gracillaria sp. were better compared to other types of alga used as natural food for abalone culture, which both provided better result. Juveniles of abalone species Haliotis asinina fed the red alga Gracilariopsis heteroclada and artificial diet showed faster growth in terms of both total body weight and shell length than those fed the red alga Kappaphycus alvarezii (Capinpin and Corre, 1996). Capinpin and Corre (1996) also suggested that Gracillaria sp. could be used as natural food to stimulate the growth and found to be in proportion as food for abalone culture.

Abalone species Haliotis asinina and $H$. squamata preferred alga as their food, however the growth rate was found slow. Priyambodo et al. (2005) and Susanto et al. (2007) suggested that growth rate of abalone during the culture and fed with alga showed to be slow and heterogeneous (not equal). However, insufficient food availability during the early life stages strongly influences survival and growth of postlarval abalone (Kawamura et al., 1998; Takami et al., 2000; Sasaki and Sheperd, 2001; Roberts et al., 2001), although Onitsuka et al. (2008) reported that food limitation was not the only factor affecting the survival of abalone.

Predation is another important factor affecting the survival rate of abalone. Abalone cultured in wild condition, particularly the postlarval and juveniles, are potentially preyed upon by various carnivorous animals, such as polychaetes (Naylor and Mcshane, 1997), fishes (Shibui, 1971; Sheperd and Turner, 1985), crabs
(Shibui, 1971; Mower and Sheperd, 1988) and starfish (McShane and Naylor, 1997).Thus, a better system had to be developed to reduce this threats.

Besides of substrate and food factors, water quality became one of important factors that affected the growth and survival rate of abalone (Setyono, 2006). A stabil temperature could increase the growth of some species of abalone. Haliotis tuberculata gained $18 \mathrm{~mm} / \mathrm{year}$ at temperature $20^{\circ} \mathrm{C}$, Haliotisfulgens showed growth increasing at temperature above $20^{\circ} \mathrm{C}$ (Stickney, 2000). Peck (1989) suggested that temperature ranged at $8.5-9.0^{\circ} \mathrm{C}$ became the lowest temperature to Haliotis tuberculata. At lower temperature than therange, abalone would be difficult to absorb food and so the growth became slower. Based on result of laboratory research, the maximum growth of abalone would be gained at temperature $20^{\circ} \mathrm{C}$. In Europe as reported by Hayashi (1980), low water temperature during the winter arrested growth, so that the main growth occurred in summer. Conversely, the growth pattern of abalone cultured in land-based culture system at Israel was opposite to the pattern in the natural habit and spawning occurred during the winter (Shpigel et al., 1996). While Koike (1978) maintained the growth of Haliotis tuberculata reared in a land-based facility was accelerated due to the constant temperature $20^{\circ} \mathrm{C}$.

Abalone most found in high salinity of waters liked sea waters which had range of salinity 30-35 ppt. For example, Haliotis tuberculata could not live in brackish water (Fretter and Graham, 1962). The same opinion was suggested by Jeffreys (1865) that Haliotis tuberculata was easily to be stricken with disease at lower salinity (below 14 ppt Optimal salinity suited to abalone growth ranged at 33-35 ppt, while range above $35 \mathrm{ppt}$ would affect not optimal to the growth (Fallu, 1991). Stickney (2000) stated that the optimum growth of abalone depended on each species and also water quality, and salinity had to be kept at range 32-35 ppt. Based on Peck (1983)'s laboratory research, resulted that the survival rate of abalone was very low at salinity $14 \mathrm{ppt}$, while the rate was good at salinity $24 \mathrm{ppt}$

$\mathrm{pH}$ affected the toxicity of chemical compounds. At waters with low $\mathrm{pH}$, therewere found manynontoxic ammonium (innocuous). Though, at alkali condition (high rate of $\mathrm{pH}$ ), there were found many unionized ammoniac and 
toxic. Unionized ammoniac was easily absorbed into aquatic organism's body compared with the ammonium (Tebbut, 1992). Most of aquatic organisms were sensitive to $\mathrm{pH}$ changing and prefer to $\mathrm{pH}$ ranged at 7.0-8.5 (Novotny and Olem, 1994). While Stickney (2000) suggested that abalone needed good water quality for its growth, thus must be cultured in clean area of waters. Optimum $\mathrm{pH}$ rate to gain an optimal growth of abalone was found at 8.0.

Dissolved oxygen (DO) was one of the limited factor in waters. All of aquatic organisms need oxygen to fulfill their metabolism activity. Based on result, DO measured over the research were ranged at $8.2 \mathrm{mg} / \mathrm{L}-10.1 \mathrm{mg} / \mathrm{L}$. Compared to water quality standard, then could be described that DO found in research were in fixed range of DO for culture organism.

\section{Conclusions}

Based on analysis of daily growth rate of abalone, absolute growth of abalone, and water quality measurements, could be obtained some conclusions, i.e:

1. Natural foods fed during the research were together affecting the daily growth rate of abalone, though the highest rate were found in abalone fed with Ulva sp.

2. The absolute growth of abalone was found at treatment with Ulva sp.

3. Water quality at Hulaliu waters measured during the research were found in optimal range for abalone growth.

\section{Recommendation}

Based on the conclusions, some recommendation were suggested, i.e:

1. The research could be continued with some levels of each water quality parameters to investigate the feeding habit of abalone.

2. The research could be continued with different type of food whether natural food or artificial food to investigate the preference of abalone appetite and the influence for its growth.

3. Abalone culture in Hulaliu waters had to be considered to be developed for the waters was suited as culture area of abalone.

\section{Acknowledgements}

We would like to thank Directorate General For Higher Education, Department of
National Education that had funded this study through Research of national priority MP3EI with a letter agreement Ref. No. 294/SP2H/PL/DIT.LITABMAS/VII/2013 dated $15^{\text {th }}$ July 2013.

\section{References}

Capinpin, E.C. and K.G. Corre. 1996. Growth rate of the Philippine abalone, Haliotis asinina fed an artificial diet and macroalgae. Aquaculture, 144:81-89.

Effendi, M.I. 1979. Metoda Biologi Perikanan. Yayasan Dewi Sri, Bogor. 112 p.

Fallu, R. 1991, Abalone Farming, Fishing News Book, Oxford, ISBN, 0-85238-171-9.

Fretter, Y. and A. Graham. 1962. British Prosobranch Mollusks: Their Functional Anatomy and Ecology. London, Ray Society Publication, 144, $755 \mathrm{p}$.

Hayashi, I. 1980. Structure and growth of a shore population of the ormer, Haliotistuberculata. Journal of the Marine Biological Association of the U.K., 62:835844.

Jeffreys, J.G. 1865. British Conchology, or an account of Mollusca which now inhabit the British Isles and the surrounding seas. Volume III. Marine shells, comprising the remaining Conchifera, the Solenoconchia, and Gastropoda as far as Littorina. London, Van Voorst, 394 p.

Kawamura, T., R.D. Roberts, and H. Takami. 1998. A review of the feeding and growth of postlarval abalone. J. Shellfish Res., 17:615-625

Koike, Y. 1978. Biological and ecological studies on the propagation of the ormer, Haliotis tuberculata (L.). I: Larval development and growth of juveniles. La Mer, 16:124-136.

Latuihamallo, M. 2011. Pengaruh Intensitas Cahaya dan Jenis Pakan Terhadap Pertumbuahn Abalon (Haliotis squamata) Pada Sistem Budidaya. Disertasi.

McShane, P.E. and J.R. Naylor. 1997. Direct estimation of natural mortality of the New Zealand abalone, Haliotis iris. N.Z. J. Mar. Freshw. Res., 31:135-137.

Mower, A.G.J. and S.A. Sheperd. 1988. The crab fauna of West Island, South Australia: their abundance, diet, and role as predators of abalone. Trans. R. Soc. S. Aust., 112:83-86.

Naylor, J.R. and P.E. McShane. 1997. Predation by polychaete worms on larval and postsettlement abalone Haliotis iris (mollusca: Gastropoda). J. Exp. Mar. Biol. Ecol., 214:283-290.

Novotny, V. and H. Olem. 1994. Water Quality: Prevention, Identification, and Management 
of Diffuse Pollution. Van Nostrand Reinhold, NY. Pp. 1054.

Onitsuka, T., T. Kawamura, T. Horii, N. Takiguchi, and Y. Watanabe. 2008. Survival, growth and recruitment of abalone Haliotis diversicolor in Sagami Bay, Japan. J. Shellfish Res.

Peck, L.S. 1983. An investigation into the growth and early development of the ormer, Haliotis tuberculata (L.). Ph.D Thesis (C.N.A.A.), Portsmouth Polytechnic, Portsmouth, UK, $386 \mathrm{p}$.

- 1989. Feeding, growth, and temperature in the ormer, Haliotis tuberculata (L.), Prog. Underwat. Sci., 14:95-107.

Priyambodo, B., Y. Sofyan, dan I.B.M. Suastika Jaya. 2005. Produksi benih tiram abalon (Haliotis asinine) di Loka Budidaya Laut Lombok. Prosiding seminar nasional tahunan hasil penelitian perikanan dan kelautan.UGM. Yokyakarta, $5 \mathrm{hlm}$.

Rahmawati, R., I. Rusdi, dan B. Susanto. 2008. Studi tentang pertumbuhan abalon Haliotis squamata (reeve, 1986) dengan pemberian pakan makroalga yang berbeda. Prosiding Seminar Nasional Perikanan 2008. Teknologi Budidaya Perikanan Sosial Ekonomi Kelautan dan Perikanan, hlm. 342-349.

Roberts, R.D., C. Lapworth, and R.J. Barker. 2001. Effect of starvation on the growth and survival of post-larval abalone Haliotis iris. Aquaculture, 200 : 323-338.

Sasaki, R. and S.A. Sheperd. 2001. Ecology and post-settlement survival of the Ezo abalone, Haliotis discus hannai, on Miyagi coasts, Japan. J. Shellfish Res., 20 : 619-626.
Setyono, D.E. 2006. Induction Spawning For The tropical Abalone ( Haliotis asinina) In The Laboratory, Indonesian Aquaculture Journal, Vol. 1 Number 1, 2006, ISSN $0215-0883$.

Sheperd, S.A. and J.A. Turner. 1985. Studies on southern Australian abalone (genus Haliotis). VI. Habitat preference and abudance and predators of juveniles. J. Exp. Mar. Biol. Ecol., 93:285-298.

Shibui, T. 1971. Experimental studies on the predatory animals of young abalone. Bull. Jpn. Soc. Sci. Fish., 37:1173-1176.

Shpigel, M., A. Marshall, I. Lupatsch, J.P. Mercer, and A. Neori. 1996. Acclimation and Propagation of the Abalone Haliotistuberculata in a Land-Based Culture system in Israel. Journal of the World Aquaculture Society, 27 (4): 435-447.

Stickney, R.R. 2000.Abalon culture. Encyclopedia of aquaculture. California, p. 1-6.

Susanto, B., I. Rusdi, I.N.A. Giri, dan T. Sutarmat. 2007. Aplikasi Teknologi Pembesaran Abalone (Haliotis squamata) Dalam Menunjang Pemberdayaan Masyarakat Pesisir. Hlm. 295-305.

Takami, H., T. Kawamura, and Y. Yamashita. 2000. Starvation Tolerance of Newly Metamorphosed Abalone Haliotis discus hannai. Fish. Sci., 66:1180-1182.

Tebbut, T.H.Y. 1992. Principles of Water Quality Control, $4^{\text {th }}$ edition. Pergamon, Oxford, U.K.

Zonneveld, N.E.A. Huisman, dan J.H. Boon. 1991. Prinsip-Prinsip Budidaya Ikan. Terjemahan PT.Gramedia Pustaka Utama. 381 hlm. 